\title{
STASAT :DNTC \\ STRATEGI RESOURCE-BASED DAN INOVASI DENGAN PENDEKATAN BIAYA DAUR HIDUP PRODUK UNTUK MENCAPAI KEUNGGULAN DAYA SAING
}

\author{
Whedy Prasetyo \\ Dosen Jurusan Akuntansi \\ Fakultas Ekonomi, Universitas Jember \\ e-mail:whedyprasetyo@yahoo.com
}

\begin{abstract}
Product development and competition continuously growing in markets to meet consumer needs as consumer, and the goal to achieve cost accuracy and effectiveness during product manufacturing process based on resource strength and weaknesses provide effort in developing internal resource capability of Small and Medium Enterprises (SME) manufacture through application of resource-based strategy (consisting of financial, physical, human and technology resources) and innovation (consisting of product innovation and internal resource) using product life cycle cost approach in achieving competitive advantage.

This research suggests that 108 assisted-partner SME manufactures in East Java, using multiple regression analysis provide result in which jointly implementing resource-based strategy and innovation will achieve product competitive advantage. In term of its contribution of the resources, however, there are only three resources, physical resource, product innovation and internal resource, which highly contribute to improve product competitive advantage.
\end{abstract}

Keywords SME manufacture, resource-based strategy, innovation, product life cycle cost, and product competitive advantage.

\section{PENDAHULUAN}

Upaya pengembangan Usaha Kecil dan Menengah (UKM) tak henti-hentinya diupayakan mulai jaman orde baru sampai sekarang. Keadaan ini menuntut kita semua yang peduli kepada keberhasilan ekonomi rakyat, dan sadar bahwa untuk memperkuat perekonomian bangsa harus dimulai dari UKM, hal ini terbukti disaat perekonomian nasional masih lesu karena dampak krisis ekonomi, UKM ternyata mampu bertahan. Bahkan eksistensinya mampu digunakan bagi jutaan korban pemutusan hubungan kerja akibat terpuruknya industri nasional. Selanjutnya perkembangan pada aspek perbankan, menunjukkan bahwa bank yang masih mampu bertahan ialah bank yang banyak membiayai UKM, karena adanya penyebaran resiko dan margin yang didapatkan lebih besar.

Dukungan terhadap pengembangan UKM, juga ditunjukkan oleh pemerintah, misalnya dengan membentuk Departemen Koperasi dan Usaha Kecil Menengah, menetapkan kebijakan yaitu pencanangan "UKM Bangkit" pada tahun 2004, Program Kompensasi Pengurangan Subsidi BBM (PKPS-BBM) melalui Lembaga Keuangan Mikro (LKM) dan Koperasi Simpan Pinjam (KSP) yang menghasilkan kredit bergulir, mewajibkan Badan Usaha Milik Negara (BUMN) menyisihkan dana pembinaan sebesar 1\%-10\% dari keuntungan bersih, serta prioritas kedua Rencana Kerja Pemerintah 
(RKP) tahun 2009 yaitu fokus ketujuh untuk meningkatkan produktivitas dan akses UKM kepada sumberdaya produktif.

Pengembangan usaha kecil sampai menengah selalu tidak dapat diikuti dengan keberhasilan perkembangan produk usahanya, hal ini disebabkan karakteristik yang ada pada diri pribadi pengusahanya akan lemahnya manajerial di dalam kemampuan merencanakan dan strategi berusaha. Karakteristik kelemahan ini mengakibatkan ketidakmampuan produk usahanya untuk berkembang dan menyesuaikan atas pengaruh perubahan terhadap timbulnya ancaman yang muncul dari dalam lingkungan usaha (Hebert and Bradley, 1993; dan Gaskill, Van Auken and Manning, 1993). Lebih lanjut menurut Vinnell and Hamilton (1999) berpendapat bahwa proses perkembangan keberhasilan produk usaha UKM harus ditekankan pada keberhasilan dukungan pengembangan internalnya dahulu, yang merupakan sumber kekuatan utama peningkatan kinerja dan kebijakan strategi bersaing. Baswir (1998) menyatakan bahwa setiap dukungan atas pengembangan usaha kecil sekaligus menengah, sebagian besar selalu mengalami kegagalan akibat kelemahan utama yang melekat dari dalam lingkungan sendiri (internal), yaitu peluang untuk selalu meningkatkan kemampuan manajerial yang berupa; kelemahan pengorganisasian dan kelemahan perencanaan usaha serta strategi bersaing, akibatnya perkembangan usaha hasil produknya selalu mengalami kegagalan bersaing di pasaran.

Triyuwono (1999) menyatakan bahwa kelemahan di dalam kemampuan manajerial dari pengelola usaha kecil dan menengah, khususnya yang terdapat di Jawa Timur dapat merambat pada aspek lainnya, seperti: lemahnya manajemen permodalan yang berakibat terbatasnya modal kerja yang dimiliki dan ketidak mampuan mencari sumber-sumber permodalan yang murah. Aspek yang lain adalah pemasaran, seperti; ketidak mampuan industri kecil untuk memenuhi spesifikasi dan standar mutu pemesan, ketidak mampuan untuk mengakses informasi pasar, dan kurangnya pemahaman terhadap tata-niaga dan prosedur ekspor. Aspek bahan baku, seperti; kelemahan dalam mencari bahan baku yang murah, ketidak mampuan dalam mencari pemasok yang dapat menyediakan bahan baku sesuai dengan timing yang dikehendaki, ketidak mampuan dalam menentukan dan menilai kualitas bahan baku. Aspek teknologi, seperti; ketidak mampuan membuat desain produk yang bersifat trendy, fashion, dynamics, dan contemporary, lemah dalam pengendalian kualitas, dan inovasi produkproduk baru. Dan aspek selanjutnya yang terakhir adalah tenaga kerja, seperti; rendahnya keterampilan (skill) tenaga kerja.

Hasil penelitian Urata (Riyanti, 2003) berpendapat bahwa penghambat keberhasilan usaha UKM manufaktur di lima kota di Indonesia Yaitu Bali, Surabaya, Semarang, Yogyakarta, dan Lampung pada rendahnya kemampuan internal manajerial merupakan hal mendesak yang harus diatasi, yaitu atas kontrol kualitas atau perbaikan produksi produk (sebesar 28,9 persen) untuk mencapai efisiensi biaya. Lebih lanjut hasil penelitian Nugent and Yhee (2002) menyatakan bahwa perkembangan Usaha Kecil dan Menengah di Korea dalam keberhasilan perkembangan produk usaha, yaitu dengan mendasarkan pada kemampuan internal memberikan kekuatan sebagai strategi mengelola seluruh aspek kemampuan bersaingnya, mulai dari keuangan, bahan baku, sumber daya manusia, sampai pada teknologi yang mendukung proses operasinya.

Langkah pengembangan produk hasil usaha dengan mendasarkan pada strategi kemampuan internal tersebut, dijelaskan pada hasil studi Black and Boal (1994) menyatakan bahwa hasil dari strategi kemampuan internal, yaitu dengan melaksana- 
kan strategi resource-based akan didapatkan kemampuan untuk mengelola dan menjaga strategi perusahaan sesuai dengan sumber daya yang dimiliki, sehingga dapat mencapai dan mempertahankan posisi keunggulan daya saing produk dengan kemampuan memperhitungkan dan memonitor proses produksi untuk mencapai keakuratan biaya produk dan pendapatan yang akan diperoleh, sehingga risiko kerugian dapat dikurangi. Lebih lanjut Hariadi (2003) berpendapat bahwa dengan kemampuan di dalam melakukan analisis intern akan dapat mengungkapkan potensi kekuatan utama yang bersumber dari kapabilitas dan sumber daya yang dimiliki usaha, sehingga akan menentukan tingkat kompetensi dan keunggulan bersaing usaha yang terus menerus, dan akan besar pengaruhnya dalam mendukung strategi usaha.

Secara internal, suatu usaha perlu untuk memiliki kompetensi khusus yang dicari dari kemampuan internal (resourcebased theory) (Grant, 1991 dan 1999; Mahoney and Pandian, 1992; Mosakowski, 1993 dan 1998; Mahoney, 1995; Schroeder, Bates and Junttila, 2002). Lebih lanjut Grant (1999) menyatakan bahwa strategi resourcebased sebagai kapabilitas sumber daya internal usaha manufaktur atas dimensi sumber daya keuangan, fisik, manusia, teknologi dan reputasi organisasi memberikan ketetapan arah tindakan, yang berfungsi sebagai dasar yang aman di dalam upaya mencapai keunggulan daya saing untuk mencapai keuntungan besar dari hasil perhitungan biaya secara akurat dan resiko kegagalan yang telah diantisipasi.

Pengaplikasian atas teori strategi resource-based ini, Black and Boal (1994) berpendapat bahwa strategi yang tidak hanya untuk usaha manufaktur besar saja yang bisa menerapkannya, namun usaha manufaktur dibawahnya dapat meraih keunggulan bersaing produk dengan menciptakan kapabilitas dari sumber daya internal, yaitu atas aspek keuangan, fisik, manusia, teknologi yang lebih baik dan kreatif, sedangkan untuk aspek sumber daya reputasi lebih digunakan untuk usaha besar karena kekuatan posisi bersaingnya. Lebih lanjut Suryana (2003) berpendapat bahwa pengembangan posisi bersaing hasil produk UKM lebih difokuskan pada keberhasilan strategi yang dirumuskan dan diidentifikasikan pada kapabilitas sumber daya internal melalui strategi resource-based yang bisa menciptakan produk unggul untuk memperbesar pangsa produksi, dengan menentukan harga jual produk berdasarkan informasi biaya penuh produk yang dihitung secara cermat selama proses pembuatan produk, sehingga keberhasilan produk di masa depan akan dapat lebih dipertahankan. Penerapan strategi resource-based bagi UKM menurut Widjaja (1993) akan lebih murah dan ampuh karena bisa memanfaatkan kemampuan internahya di dalam pengelolaan aktivitas pembuatan produk secara efektif dan efisien. Lebih lanjut Mosakowski (1993) menyatakan bahwa strategi resource-based dengan di dukung inovasi yang mendasarkan pada biaya daur hidup selama proses produksi produk dihasilkan keakuratan dan efisiensi biaya produk, sehingga usaha dapat mencapai ketepatan atas hasil produk. Dalam konteks persaingan produk, mempertahankan suatu produk agar tetap diperlukan konsumen aktivitas inovasi pengembangan produk merupakan hal penting yang harus diperhatikan, yaitu atas penciptaan, pemilihan, dan pengembangan atau peningkatan produk, proses, dan teknologi dengan mendasarkan daur hidup produk untuk mengukur kapabilitas strategi inovasi atas orientasi aktivitas desain, proses produksi, inovasi produk, sumber eksternal, sumber internal, dan tingkat investasi untuk mencapai keunggulan daya saing produk yang mampu menghasilkan produk inovatif, yaitu produk yang memberikan nilai tambah baru dan kekuatan baru dalam posisi per- 
saingan untuk menarik keinginan konsumen dan mempertahankannya (Butler 1988).

Tatikonda and Rosenthal (2000) menyatakan bahwa pencapaian keunggulan daya saing produk inovatif yang dihasilkan dari proses inovasi sebagai konsep pelaksanaan strategi yang digunakan, dan atau dengan strategi yang mendukung lainnya memberikan dukungan atas terciptanya efektivitas pengembangan dan penciptaan produk, yang mendasarkan pada keseluruhan biaya produk yang dikeluarkan atas daur hidup produk yang terjadi. Desain produk yang dihasilkan dengan mendasarkan pada pendekatan biaya daur hidup produk, akan memberikan kemampuan manajemen di dalam menentukan strategi internal yang didasarkan kekuatan dan kelemahan, dan memilih strategi inovasi yang digunakan, sehingga desain produk yang dikeluarkan mempunyai keunggulan daya saing produk secara berkesinambungan (Liang, Peien and Shuangxia, 2001).

Berdasarkan kajian teori yang dihasilkan dari penelitian tersebut di atas, maka penelitian ini membahas upaya pengembangan UKM produk manufaktur atas pelaksanaan strategi resource-based dan inovasi dengan pendekatan biaya daur hidup produk untuk mencapai keunggulan daya saing. Yang membedakan penelitian ini dengan penelitian sebelumnya yaitu mengaplikasikan strategi resources-based dan inovasi dengan mendasarkan pendekatan biaya daur hidup produk untuk mencapai efisiensi dan keakuratan biaya produk selama daur hidup produk, dan penetapan harga produk dengan mendasarkan pada kemampuan internal, yang pada hasil penelitian Mosakowski (1993) hanya inovasi yang dilakukan pendekatan biaya daur hidup produk saja, sedangkan hasil penelitian Black and Boal (1994) mendasarkan strategi resource-based pada pendekatan biaya daur hidup produk, dan pada kajian teoritis dan hasil penelitian sebelumnya (Butler 1988;
Grant, 1991; Mahoney and Pandian, 1992; Mosakowski, 1993 dan 1998; Black and Boal, 1994; Mahoney, 1995; Schroeder, Bates and Junttila, 2002; Tatikonda and Rosentha,1 2000; dan Liang, Peien and Shuangxia, 2001) kedua strategi tersebut dipisahkan, serta sampel yang digunakan penelitian yaitu pada perusahaan besar yang bergerak di bidang manufaktur, sedangkan penelitian ini sampelnya yaitu UKM di bidang manufaktur.

Berdasarkan penjelasan di atas perhatian utama pada penelitian ini difokuskan pada pencapaian keunggulan daya saing produk, yaitu menciptakan nilai tambah produk yang dihasilkan, melalui potensi sumber daya dan inovasi yang mengarah pada keahlian secara internal dengan mendasarkan pada pendekatan biaya proses pembuatan produk selama daur hidup produk yang dihasilkan.

\section{KAJIAN TEORI \\ UKM Manufaktur}

Di Indonesia sampai saat penelitian ini dilakukan, pengertian dan kriteria UKM tidak memiliki satu definisi yang standar, Saadah (2002) berpendapat bahwa Usaha Kecil dan Menengah didefinisikan dengan pengertian atau penjelasan yang berbeda tergantung pada kepentingan organisasi, yang bukan sebagai usaha berskala besar dan atau go public di bursa saham. Lebih lanjut Departemen Koperasi dan Pembinaan Pengusaha Kecil (1995) mengelompokkan UKM berdasarkan asset (di luar tanah dan bangunan) paling banyak Rp.200.000.000 (dua ratus juta rupiah) dan nilai penjualan per tahun sebesar Rp.5.000.000.000 (lima miliar rupiah) atau kurang.

Untuk dapat mencapai keunggulan hasil produk usaha yang mempunyai keunggulan daya saing, maka dituntut UKM manufaktur untuk dapat memiliki daya saing yang tinggi dan kemampuan manajerial di dalam mencapai keunggulan produk dengan 
bertumpu pada kepercayaan dan kemampuan sendiri, sehingga akan dapat bersaing di dalam pasar. Keunggulan daya saing produk inilah, yang mendasari penelitian ini untuk dapat di adopsi oleh UKM manufaktur, melalui strategi resource-based dan inovasi yang menekankan pada kemampuan internal, di dalam upaya mencapai hasil produk yang diterima oleh konsumen dengan pendekatan biaya daur hidup produk menuju pencapaian keunggulan daya saing produk.

UKM manufaktur dalam dunia usaha nasional dirasakan semakin penting. UKM manufaktur telah mampu membentuk suatu kegiatan usaha yang mampu memperluas lapangan kerja, dan memberikan pelayanan ekonomi yang luas pada masyarakat, dan dapat berperan dalam proses pemerataan dan peningkatan pendapatan masyarakat, serta mendorong pertumbuhan ekonomi dan berperan dalam mewujudkan stabilitas nasional pada umumnya dan stabilitas ekonomi pada khususnya atas kedudukannya, potensi dan perannya. UKM manufaktur merupakan wujud nyata dari self employed yang dilakukan oleh masyarakat strata bawah (Setyawan, 2004) dan menengah. Akan tetapi kenyataannya, menunjukkan bahwa UKM manufaktur masih belum dapat mewujudkan kemampuan dan perannya secara optimal dalam perekonomian nasional. Hal ini disebabkan seperti kebanyakan unit usaha kecil dan menengah lainnya, UKM manufaktur masih belum dikelola secara professional di dalam kemampuannya atas pelaksanaan operasinya, keadaan yang tidak terlepas dari belum adanya strategi, dan rencana usaha yang mampu diterima oleh pasar dengan disesuaikan tingkat kemampuan internalnya (Kuncoro, 1996).

Porter (1993 dan 1996) menyatakan bahwa kemampuan internal menjadi bagian penting dalam mengetahui kekuatan dan kelemahan untuk mengatasi permasalahan hasil produk. Kondisi yang sesuai dari karakteristik usaha manufaktur dengan memfokuskan awal kemampuan internal dalam proses selama produksi, dan memberikan dukungan atas keberhasilan dan ketepatan pencapaian produk (Miller and Friesen, 1984). Selanjutnya Nugent and Yhee (2002) menyatakan bahwa UKM manufaktur mempunyai kekuatan yang dapat digunakan sebagai sumber motivasi untuk meningkatkan kemampuan perkembangan produk usahanya dalam menghadapi hambatan usaha melalui pengembangan kekuatan internal sumber daya yang dimilikinya, karena UKM manufaktur mempunyai sumber keunggulan internal pada semua aspek produksinya, sehingga terwujud pencapaian efektifitas dan hasil produksi optimal. Kekuatan internal sumber daya memberikan kemampuan khusus menciptakan produk unggul untuk memperbesar pangsa produksi, yaitu produk bermutu dengan harga rendah berpedoman pada konsumen hanya dibebani biaya-biaya aktivitas penambah nilai (Mosakowski, 1993).

Lebih lanjut Mosakowski (1998) berpendapat bahwa konsep strategi internal akan terwujud melalui strategi resourcebased yang memberikan motivasi untuk selalu meletakkan keunggulan daya saing produk dengan menciptakan nilai tambah tinggi, atas ketelitian biaya dalam memperhitungkan secara cermat sumber daya yang dikeluarkan atas keuangan, fisik, manusia, teknologi dan reputasi organisasi untuk aktivitas penambah nilai bagi konsumen. Pencapaian keunggulan daya saing produk dengan mendasarkan kapabilitas sumber daya internal, akan mencapai keuntungan tinggi secara berkesinambungan dan efektif yang akan sulit ditiru atau disaingi dengan menambahkan strategi berupa strategi inovasi (McGrath, et al., 1996).

Dengan menggunakan strategi resource-based dan inovasi, maka peneliti berasumsi dunia usaha Indonesia khususnya UKM manufaktur akan bangkit dan 
berusaha menciptakan produk dengan kapabilitas khusus dari sumber daya internal usahanya, dan tidak lagi mengandalkan strategi kekuatan pasar seperti monopoli dan fasilitas perdagangan. UKM manufaktur diharapkan mempunyai kemampuan berani untuk berpikir kreatif, dan mengetahui cara mengembangkan sumber daya internal dan inovasi secara kreatif pula. Riyanti (2003) berpendapat bahwa tumbuhnya kreatifitas dan inovasi UKM yang bersumber dari internal memberikan pemikiran kreatif berupa kemampuan mengenali pasar, memproduksi dan memasarkan barang, atau cara proses pembuatan produk, sebagai kemampuan dalam mengenali masalah, pemecahan masalah dan pengambilan keputusan usaha.

\section{Biaya Daur Hidup Produk}

Onkvisit dan Shaw (1986) menyatakan bahwa produk usaha akan mempunyai jangka waktu untuk memenuhi kebutuhan konsumen, jangka waktu mulai produk dihasilkan sampai pada produk tersebut tidak lagi mampu untuk memenuhi keinginan konsumen, jangka waktu itu yang disebut sebagai daur hidup produk. Lebih lanjut Mulyadi (2001) berpendapat bahwa biaya daur hidup produk sebagai keseluruhan biaya yang bersangkutan dengan produk selama daur hidupnya, yang meliputi: biaya pengembangan (perencanaan, desain, pengujian), biaya produksi (aktivitas pengubah bahan baku menjadi produk jadi), dan biaya dukungan logistik (iklan, distribusi, jaminan, dan sebagainya). Konsep yang memberikan perhatian terciptanya efektifitas biaya yang dikeluarkan selama daur hidup produknya (Emblemsvaq, 2001).

Butler (1988) berpendapat bahwa pendekatan internal biaya produk selama proses pembuatan produk yang dijalankan, memberikan pedoman yang digunakan sebagai pengembangan proses inovasi produk, efektifitas harga produk dan perhitungan laba yang akurat, serta antisipasi timbulnya resiko kegagalan selama proses pembuatan produk. Kemampuan memperhitungkan biaya produk, memberikan dorongan keinginan usaha manufaktur dalam proses pengembangan bersaing usaha terhadap lingkungan persaingan yang ada atas keunggulan produk usaha (Human and Provan, 1997).

\section{Strategi Resource-Based}

Mosakowski (1993 dan 1998) menyatakan bahwa perhatian atas penggunaan sumber daya internal sebagai strategi usaha dalam rangka menghadapi keberhasilan proses pembuatan produk, harus dikembangkan bagi keseluruhan usaha manufaktur melalui strategi yang berbasis pada pengembangan sumber daya internal secara superior (resource-based strategy) atas 5 (lima) sumber daya, dengan karakteristik sebagai berikut: 
Tabel 1: Klasifikasi Kelima Strategi Resource-Based

\begin{tabular}{ll}
\hline \multicolumn{1}{c}{ Sumber Daya } & \multicolumn{1}{c}{ Karakteristik Utama } \\
\hline Sumber daya keuangan & $\begin{array}{l}\text { Kemampuan untuk memperhatikan dan menciptakan dana } \\
\text { selama proses produk }\end{array}$ \\
Sumber daya fisik & $\begin{array}{l}\text { Penentuan hasil produksi produk sebagai potensi } \\
\text { keunggulan mutu dan efektifitas biaya }\end{array}$ \\
Kemampuan dan ketrampilan seluruh karyawan di dalam \\
Sumber daya manusia & $\begin{array}{l}\text { Fempertahankan keunggulan kompetitif produk } \\
\text { Sumber daya teknologi }\end{array}$ \\
& $\begin{array}{l}\text { dan pembuatan kualitas produk } \\
\text { Reputasi perusahaan di dalam hubungannya dengan } \\
\text { pemasok komponen dan konsumen }\end{array}$ \\
\hline
\end{tabular}

Menurut Grant (1991 dan 1999) berpendapat bahwa karakteristik kelima dimensi strategi resource-based mempunyai tujuan peningkatan nilai strategis keunggulan produk secara berkesinambungan. Lebih lanjut Grant (1999) menyatakan bahwa kelima dimensi utama strategi resource-based yaitu, sumber daya keuangan untuk mengidentifikasi kemampuan usaha melakukan perhitungan dana dan pendapatan, serta resiko kerugian secara internal yang ditentukan berdasarkan keseluruhan pengeluaran biaya proses pembuatan produk. Sumber daya fisik menjelaskan, hasil produk usaha memiliki efisiensi, dan keakuratan penentuan biaya dan pendapatan yang diharapkan, sebagai petunjuk penentuan harga jual produk kepada konsumen dengan mendasarkan kekuatan dan kelemahan sumber daya. Sumber daya manusia ditujukan pencapaian efektifitas produksi, dengan memberikan tanggung jawab karyawan untuk memperhitungkan biaya dan pendapatan produk selama produksi. Sumber daya teknologi menunjukkan upaya pencapaian efektifitas proses pembuatan dan pengembangan produk untuk mencapai kualitas lebih baik, dengan mendasarkan kemampuan yang dimiliki. Terakhir sumber daya reputasi organisasi memberikan hubungan baik konsumen atas hasil produk mampu diterima, dan kepercayaan pemasok atas pembelian berkelanjutan.
Menurut Black and Boal (1994) berpendapat bahwa keunggulan daya saing produk strategi resource-based dengan mendasarkan keseluruhan biaya proses pembuatan produk memberikan kehandalan, mobilitas, relevansi dan keterpaduan sumber daya atas kekuatan dan kelemahan yang dimilikinya. Mendasarkan pada strategi resource-based usaha manufaktur akan mendapatkan petunjuk mudah melakukan evaluasi yang menekankan kemampuan internal atas kekuatan dan kelemahan, sehingga dapat dilaksanakan dan mencapai hasil yang diperhitungkan (Lovas and Ghoshal, 2000).

Dollinger and Golden (1992) menyatakan bahwa keunggulan daya saing produk yang mendasarkan kesesuaian sumber daya dari dalam usaha, sebagai strategi yang mampu memberikan masukan akurat pencapaian strategi bersaing produk dibandingkan pesaing. Kemampuan internal yang dapat dikelola melalui penerapan strategi resource-based, memberikan instance dengan menekankan pentingnya perhatian pendekatan biaya internal bagi usaha manufaktur (Rindova and Fombrun, 1999).

\section{Strategi Inovasi}

Dalam melakukan inovasi, suatu usaha manufaktur harus mengembangkan strategi inovasi formal dan menyeluruh, yaitu strategi menetapkan tujuan-tujuan 
pengusaha dalam menjalankan inovasi dengan pengetahuan dan fokus atas produk yang dihasilkan, untuk mempunyai kemampuan menggambarkan bagian-bagian dan cara-cara menciptakan keunggulan daya saing yang mampu meningkatkan nilai konsumen lebih baik dengan biaya yang sama atau lebih rendah dibandingkan pesaing (Drucker, 2002).

Pada kajian empiris Butler (1988) berpendapat bahwa strategi inovasi atas daur hidup produk akan melekat pada tiga tahap, yaitu; pengembangan, pengetahuan keseluruhan tahap, ketergantungan teknologi dan keinginan pemakai yang diharapkan dari teknologi, dan tingkat investasi pada inovasi. Dari ketiga tahap, kemudian didapatkan enam dimensi yang mengukur kapabilitas strategi inovasi manajemen dengan pengertian dan pemahaman berbeda, sehingga pemilihannya harus sesuai kondisi dan keinginan yang ingin dicapai usaha, keenam variabel tersebut, adalah:

1. Orientasi Aktivitas Desain

Mengintegrasikan kegiatan operasional, pengembangan kreasi, perhatian dan perluasan produk, serta teknologi yang didasarkan kemampuan keseluruhan proses pembuatan produk untuk mampu menjadikan strategi faktor pemecahan masalah dalam mengatasi persoalan persaingan usaha dan keakuratan produk yang diinginkan konsumen.

2. Proses Produksi

Pencapaian hasil dengan mendapatkan keakuratan proses pembuatan produk yang didasarkan kemampuan perencanaan, baik hasil akhir atau bagaimana cara mencapai hasil akhir tersebut, sebagai pedoman menghasilkan produk dan proses keunggulan daya saing.

3. Inovasi Produk

Pedoman penting alokasi sumber daya dalam proses pembuatan produk untuk mencapai efisiensi produk dan keuntungan hasil akhir yang diinginkan, mampu menumbuhkan kreatifitas pengaruh generalisasi ide dan keberhasilan implementasi inovasi, dengan mendasarkan kecukupan sumber daya dan dukungan manajemen.

4. Sumber Eksternal

Perhatian pada inovasi yang mendasarkan sumber-sumber eksternal dalam mencapai keunggulan daya saing produk melalui pembelian, perjanjian lisensi, akuisisi usaha bisnis lain, menjalin kerjasama dengan pemasok, konsumen, atau usaha bisnis lain.

5. Sumber Internal

Kapabilitas yang menekankan usaha inovasi dari dalam atas kekuatan dan kelemahan sumber daya usaha yang dimiliki, untuk mencapai ketepatan hasil akhir produk selama proses pembuatan dan pencapaian keunggulan daya saing produk atas tingkat keuntungan dan pengurangan resiko kerugian.

6. Tingkat Investasi

Kemampuan usaha untuk mendukung pengembangan dan keberhasilan strategi inovasi yang dijalankan dalam meningkatkan kemampuan dan kompetensi produk yang dihasilkan untuk keunggulan daya saing yang mencakup kebutuhan keuangan, teknologi, dan modal SDM.

Menurut LaBahn and Krapfel (1996) berpendapat bahwa kapabilitas inovasi produk, sangat diharapkan oleh usaha kecil manufaktur untuk dapat menghasilkan kreasi dan pengenalan produk unggul, atau modifikasi produk lainnya yang sudah ada. Lebih lanjut Khan and Manopichetwattana (1989) menyatakan bahwa inovasi produk memberikan kesadaran dan perhatian kepada usaha kecil pentingnya perhatian daur hidup produk, sebagai siklus yang memberikan tuntutan bahwa produk yang dihasilkan dan direncanakan harus dapat menutup semua 
biaya dan laba tertentu selama daur hidupnya.

Inovasi atas produk yang dihasilkan memberikan fokus perhatian untuk dapat mengembangkan UKM di Indonesia atas pencapain keunggulan daya saing yang dapat diwujudkan sama dengan inovasi produk (Salim, 1999). Kemampuan melakukan inovasi, akan dihasilkan kemampuan dalam 2 (dua) hal yaitu; kemampuan mengidentifikasi pasar, dan kemampuan menciptakan produk untuk memenuhi kebutuhan pasar tersebut. Dengan kemampuan ini diharapkan pelanggan tidak meninggalkan dan memenuhi selera yang diinginkan (Hariadi, 2002).

Kemampuan menciptakan keunggulan produk melalui inovasi, haruslah di dukung kemampuan internal UKM (UKM) manufaktur, yaitu kemampuan memberikan dorongan untuk selalu menekankan kekuatan dan kelemahan sumber daya yang dimiliki, untuk terus berkembang dan berkesinambungan sejalan hasil produksi yang dapat diterima konsumen, yaitu menciptakan kreatifitas produk terus menerus, dan mengetahui pengembangan sumber daya internal secara kreatif pula (Suryana, 2003). Pengembangan kemampuan sumber daya internal usaha manufaktur, yaitu memfokuskan awal kemampuan internal proses hasil produksinya atas pencapaian keunggulan daya saing produk, dan memberikan dukungan keberhasilan dan ketepatan pencapaian proses akhir yang didasarkan kekuatan dan kelemahan (Miller and Friesen, 1984).

\section{Kerangka Penelitian}

Keterkaitan dimensi-dimensi strategi resource-based dan inovasi dengan pendekatan biaya daur hidup produk untuk mencapai keunggulan daya saing produk dapat dimodelkan, yaitu dengan mendasarkan kajian teoritis dan hasil penelitian memberikan dua pendekatan.
Pertama, yaitu strategi resource-based yang terdiri atas kelima dimensi didasarkan pendekatan biaya selama daur hidup, secara bersamaan mampu mencapai keunggulan daya saing produk (Black and Boal, 1994). Kedua, yaitu adanya hubungan logis yang mempengaruhi kelima strategi resourcebased atas strategi lain, yaitu inovasi dengan didasarkan pendekatan biaya daur hidup produk atas perhitungan biaya selama pembuatan produk untuk keakuratan biaya, perencanaan daur hidup produk dan penyesuaian desain biaya dan sumber daya yang dimiliki (Mosakowski, 1993).

Black and Boal (1994) menyatakan bahwa secara keseluruhan dimensi-dimensi strategi resource-based, dengan mendasarkan biaya daur hidup produk mampu memberikan pengaruh signifikan secara bersamaan terhadap pencapaian keunggulan daya saing produk yang dihasilkan. Sinergi ini mempunyai dua sumber utama, yaitu penghematan dan fokus.

Kapabilitas sumber daya internal yang dimiliki dalam strategi resource-based, dapat mencapai efektifitas keunggulan perhitungan biaya melalui konsep strategi inovasi yang didasarkan pendekatan biaya selama proses pembuatannya (Mosakowski 1993). Lebih lanjut McGrath, et al. (1996) menyatakan bahwa pencapaian efektifitas inovasi lebih akurat apabila didasarkan kemampuan internal usaha manufaktur dalam memahami kekuatan dan kelemahan yang dimilikinya.

Kajian empiris Butler (1988) berpendapat bahwa strategi inovasi atas daur hidup produk akan melekat pada tiga dimensi, yaitu; tahap pengembangan proses inovasi produk, pengetahuan keseluruhan tahap proses inovasi produk, ketergantungan dan keinginan pemakai yang diharapkan dari teknologi dan tingkat investasi sebagai hasil inovasi produk. Dari ketiga dimensi ini kemudian didapatkan enam variabel yang dapat mengukur strategi inovasi manajemen. 
Di sini peneliti hanya memfokuskan pada dua variabel yaitu pertama, inovasi produk, sebagai pedoman penting dalam melakukan alokasi sumber daya atas proses pembuatan produk untuk mencapai efisiensi dan keuntungan hasil akhir produk, dan kemampuan menumbuhkan kreatifitas keberhasilan implementasi inovasi, dengan mendasarkan kecukupan sumber daya dan dukungan manajemen. Variabel kedua berupa sumber internal, sebagai dasar untuk memiliki keunggulan-keunggulan dalam keahlian dan keinginan sebagai awal proses kreativitas mengembangkan, menyatukan dan mempertahankan keberhasilan usaha.
Berdasarkan penjelasan di atas, dirumuskan hipotesis penelitian ini seperti tampak pada Gambar 1.

Dengan mendasarkan pada kerangka penelitian tersebut ditetapkan hipotesis bahwa Strategi resource-based (sumber daya keuangan $\left(\mathrm{X}_{11}\right)$, sumber daya fisik $\left(\mathrm{X}_{12}\right)$, sumber daya manusia $\left(\mathrm{X}_{13}\right)$, dan sumber daya teknologi $\left(\mathrm{X}_{14}\right)$ ), serta inovasi (inovasi produk $\left(\mathrm{X}_{21}\right)$ dan sumber internal $\left(\mathrm{X}_{22}\right)$ ) dengan mendasarkan pendekatan biaya daur hidup produk mampu untuk mencapai keunggulan daya saing (Y) bagi UKM manufaktur secara simultan dan parsial.

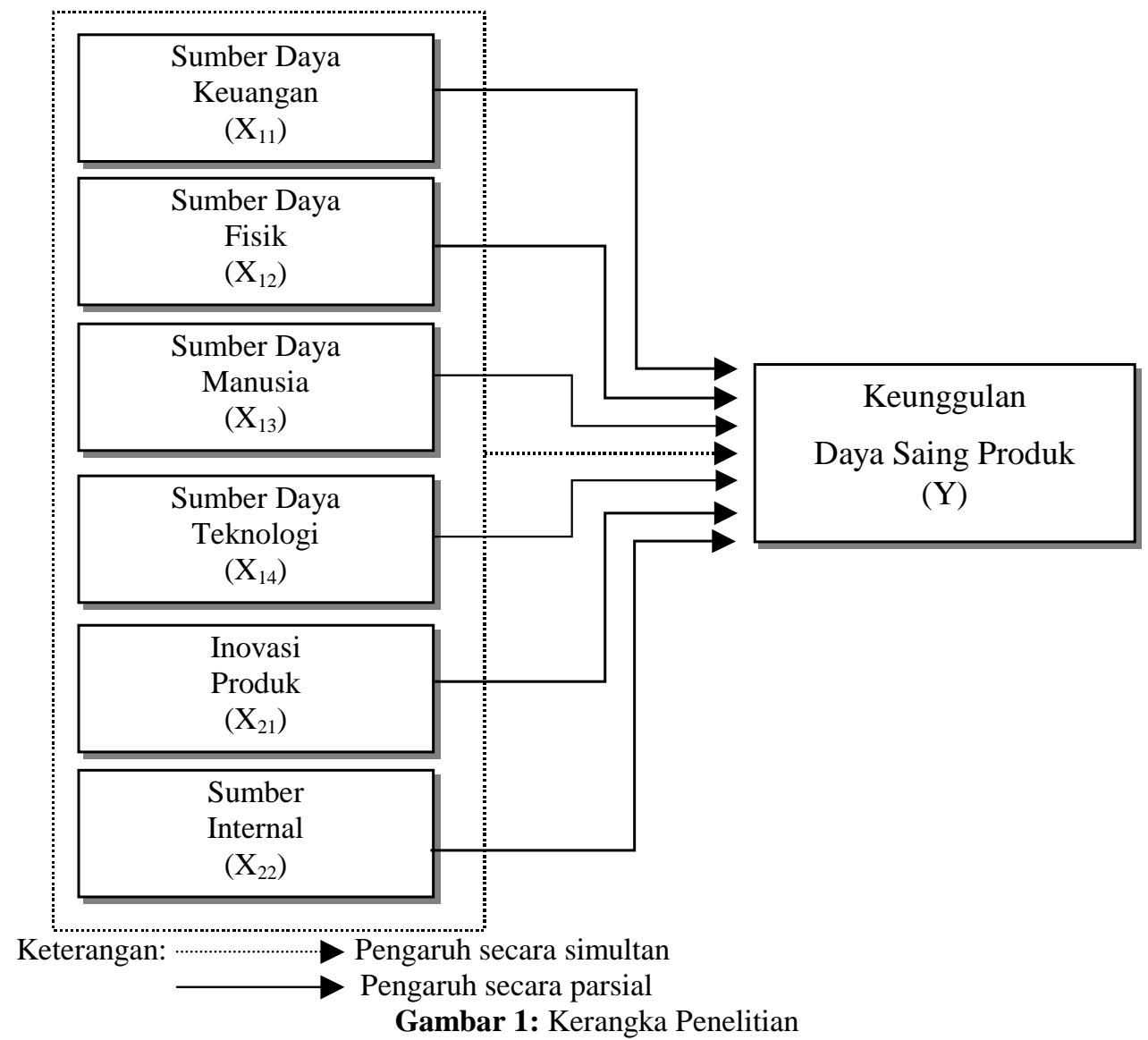




\section{METODE PENELITIAN Pemilihan Sampel dan Pengumpulan Data}

Penelitian menggunakan sebanyak 115 UKM manufaktur pada 16 Kabupaten dan 6 Kota di Propinsi Jawa Timur mitra binaan Lembaga Pengabdian Masyarakat (LPM) Universitas Brawijaya (UB) Malang dengan PT. Danareksa, dengan enam kriteria, yaitu; (1) Keterlibatan pemilik di dalam pengelolaan usahanya, (2) Merupakan usaha yang memproduksi barang jadi sampai penyerahannya kepada konsumen, (3) Mempunyai kekayaan bersih paling banyak Rp.200.000.000 (dua ratus juta rupiah), tidak termasuk tanah dan bangunan tempat usaha, dan mempunyai nilai penjualan per tahun diatas Rp.10.000.000,00 (sepuluh juta rupiah) dan sampai lebih dari Rp.1.000.000.000 (satu miliar rupiah), (4) Memiliki setidaknya dua atau lebih tenaga kerja sampai seratus (100) orang, (5) Usaha yang dijalankan tersebut telah dilaksanakan kurang lebih 2 (dua) tahun tanpa mengalami pergantian usaha mulai awal penerimaan bantuan, hal ini bertujuan memberikan kemudahan melihat perkembangan usaha atas pengaplikasian kedua strategi tersebut, dan (6) Memiliki lokasi dan sarana produksi yang bisa diamati peneliti. Berdasarkan kriteria sampel penelitian dari 115 menjadi 108 UKM manufaktur atas industri kerajinan, konfeksi dan peralatan rumah tangga.

Data dikumpulkan melalui survei dengan mengisi kuisioner yang dikirimkan kepada responden sebagai data primer. Operasional penyebaran kuisioner dilakukan dua langkah, yaitu responden tinggal memilih jawaban yang telah disediakan dengan penjelasan seperti pada saat sosialisasi dilaksanakan, dan kuisioner dikirim dan diambil sendiri oleh peneliti. Sedangkan data sekunder diperoleh dari laporan perkembangan usaha atas pencapaian keberhasilan produksi melalui perhitung- an secara tertulis dan teratur selama proses pembuatan produk, hal ini bertujuan untuk kesesuaian pengisian kuisioner dengan keadaan usaha, dan wawancara baik dengan pemilik dan karyawan (pekerja) untuk mengetahui perkembangan usaha atas pengaplikasian strategi ini.

\section{Pengukuran Variabel}

Penetapan variable mendasarkan pada kajian teoritis dari Mosakowski (1993 dan 1998), Black and Boal (1994), dan Grant (1991 dan 1999) untuk 4 (empat) dimensi strategi resource-based dan 2 (dua) strategi inovasi pada kajian teoritis Butler (1988). Keenam dimensi yang disesuaikan dengan kondisi UKM manufaktur di Jawa Timur, sehingga ada 6 variabel yang mempengaruhi $\left(\mathrm{X}_{11}\right.$ sampai $\mathrm{X}_{14}$ dan $\mathrm{X}_{21}$ sampai $\mathrm{X}_{22}$,) dan 1 (satu) variabel yang dipengaruhi (Y), dengan skala likert ukuran ordinal. Uji validitas dilakukan menggunakan korelasi product moment dari pearson, lebih besar 0.3 nilai kritisnya, hasilnya semua item pertanyaan penelitian ini yaitu valid pada signifikasi 0,3. Hasil uji reliabilitas pengukuran menggunakan cronbach's alpha dengan koefisien lebih besar 0.6, hasilnya alat pengukur (kuisioner) yang dipergunakan mengukur semua variabel dalam penelitian ini semuanya dapat diandalkan.

\section{Teknik Analisa Data}

Data yang telah terkumpul dari hasil kuisioner diolah melalui tahapan; editing, coding dan tabulasi, dengan pengujian yaitu analisis regresi berganda:

$$
\begin{aligned}
\mathrm{Y}= & a+b_{1} \mathrm{X}_{11}+b_{2} \mathrm{X}_{12}+b_{3} \mathrm{X}_{13}+b_{4} \mathrm{X}_{14} \\
& +b_{5} \mathrm{X}_{21}+b_{6} \mathrm{X}_{22} \\
& + \text { edengan signifikansi } \mathrm{a}=0,05
\end{aligned}
$$

artinya derajad kesalahan sebesar $5 \%$, alat analisis adalah:

1. Uji F, yaitu dimensi strategi resourcebasec dan inovasi dengan pendekatan 
biaya daur hidup produk secara bersamaan.

2. Uji t, yaitu dimensi strategi resourcebased dan inovasi dengan pendekatan biaya daur hidup produk secara individual.

3. Uji Asumsi Klasik, atas model regresi dengan metode penaksiran OLS melalui: Uji Normalitas, Uji Non-Multikolinearitas, Uji Non-Heteroskedastisitas, dan Uji Non-Autokorelasi.

HASIL ANALISIS DAN PEMBAHASAN Hasil Analisis

Analisis dilakukan terhadap 108 sampel UKM manufaktur dengan menggunakan analisis regresi berganda. Hasil perhitungan disajikan pada Tabel 2.
Hasil Pengujian Hipotesis Pengujian dengan uji F (Simultan)

Hasil perhitungan menunjukkan $\mathrm{F}_{\text {hitung }}$ sebesar 12.974. Nilai 12.974 ini lebih besar dari $\mathrm{F}_{\text {tabel }}$ sebesar 2.190. Hasil tersebut membuktikan bahwa variabel sumber daya keuangan ( $\left.\mathrm{X}_{11}\right)$, sumber daya fisik $\left(\mathrm{X}_{12}\right)$, sumber daya manusia $\left(X_{13}\right)$, sumber daya teknologi (X14), inovasi produk (X21), dan sumber internal $\left(\mathrm{X}_{22}\right)$ dengan pendekatan biaya daur hidup produk mampu untuk mencapai keunggulan daya saing produk (Y). Sehingga model regresi yang dihasilkan adalah:

$$
\begin{aligned}
\mathrm{Y}= & 2.277-0.027 \mathrm{X}_{11}+0.096 \mathrm{X}_{12} \\
& +0.071 \mathrm{X}_{13}-0.031 \mathrm{X}_{14}+0.517 \mathrm{X}_{21} \\
& +0.218 \mathrm{X}_{22}+\mathrm{e}
\end{aligned}
$$

Tabel 2: Hasil Analisis Regresi

\begin{tabular}{lcccl}
\multicolumn{1}{c}{ Variabel } & $\begin{array}{c}\text { Unstandardized } \\
\text { Coefficients }(\mathbf{B})\end{array}$ & $\mathbf{T}_{\text {hitung }}$ & Sig. & Keterangan \\
\hline (Constant) & 2.277 & & & \\
Sumber daya keuangan $\left(\mathrm{X}_{11}\right)$ & -0.027 & -0.679 & 0.498 & Tidak Signifikan \\
Sumber daya fisik $\left(\mathrm{X}_{12}\right)$ & 0.096 & $2.327^{*}$ & 0.022 & Signifikan \\
Sumber daya manusia $\left(\mathrm{X}_{13}\right)$ & 0.071 & 1.346 & 0.181 & Tidak Signifikan \\
Sumber daya teknologi $\left(\mathrm{X}_{14}\right)$ & -0.031 & -0.719 & 0.474 & Tidak Signifikan \\
Inovasi produk $\left(\mathrm{X}_{21}\right)$ & 0.517 & $4.419^{*}$ & 0.000 & Signifikan \\
Sumber internal $\left(\mathrm{X}_{22}\right)$ & 0.218 & $2.439^{*}$ & 0.036 & Signifikan \\
\hline & & & & \\
$\mathrm{R}$ & & $=0.660$ & & \\
$\mathrm{R}$ Square & & $=12.974$ & & \\
$\mathrm{~F}_{\text {hitung }}$ & & $=2.190$ & & \\
$\mathrm{~F}_{\text {tabel }}$ & & $=0.000$ & & \\
Sign. F & & $=0.05$ & & \\
$\alpha$ & & & & \\
\end{tabular}




\section{Pengujian dengan uji t (Parsial)}

Hasil pengujian yang dilakukan dengan besarnya nilai $\mathrm{t}_{\text {tabel }} 1.980$, adalah:

- Variabel $\mathrm{X}_{11}$, nilai $\mathrm{t}_{\text {statistik }}(-0.679)$ lebih kecil dari nilai $t_{\text {tabel }}$ (1.980), tidak mampu mendukung pencapaian $\mathrm{Y}$,

- Variabel $\mathrm{X}_{12}$, nilai $\mathrm{t}_{\text {statistik }}(2.327)$ lebih besar dari nilai $\mathrm{t}_{\text {tabel }}(1.980)$, mampu untuk mendukung pencapaian $\mathrm{Y}$,

- Variabel $\mathrm{X}_{13}$, nilai $\mathrm{t}_{\text {statistik }}$ (1.346) lebih kecil dari nilai $\mathrm{t}_{\text {tabel }}(1.980)$, tidak mampu mendukung pencapaian $\mathrm{Y}$,

- Variabel $\mathrm{X}_{14}$, nilai $\mathrm{t}_{\text {statistik }}(-0.719)$ lebih kecil dari nilai $\mathrm{t}_{\text {tabel }}(1.980)$, tidak mampu mendukung pencapaian $\mathrm{Y}$,

- Variabel $X_{21}$, nilai $t_{\text {statistik }}$ (4.419) lebih besar dari nilai $t_{\text {tabel }}$ (1.980), mampu untuk mendukung pencapaian $\mathrm{Y}$,

- Variabel $\mathrm{X}_{22}$, nilai $\mathrm{t}_{\text {statistik }}(2.439)$ lebih besar dari nilai $t_{\text {tabel }}$ (1.980), mampu untuk mendukung pencapaian $\mathrm{Y}$.

Berdasarkan pada hasil persamaan tersebut, menunjukkan bahwa hasil signifikan, yaitu terdapat pada variabel sumber daya fisik $\left(\mathrm{X}_{12}\right)$, inovasi produk $\left(\mathrm{X}_{21}\right)$, dan sumber internal $\left(\mathrm{X}_{22}\right)$, sedangkan ariabel lain tidak menunjukkan nilai signifikan.

\section{Pengujian asumsi klasik}

Pengujian asumsi klasik menggunakan 4 pendekatan sebagai berikut: Uji Normalitas:

Pengujian menggunakan Kolmogorov-Smimov Test terhadap masing-masing variabel kedua strategi yaitu resource-based dan inovasi untuk menguji sampel penelitian merupakan jenis distribusi normal dengan kaidah keputusan jika probabilitas $>0.05$. Hasil perhitungan ini diringkas dalam Tabel 3.

Berdasarkan pada hasil pada Tabel 3, untuk uji normalitas distribusi dihasilkan nilai yang lebih besar dari 0.05 . Hasil ini menunjukkan probabilitas distribusi normal model regresi dengan menggunakan model linear berganda.

\section{Uji non-multikolinieritas}

Uji ini bertujuan menetapkan model regresi tidak terjadi korelasi di antara variabel bebas, untuk mendekteksi mendasarkan hasil Variance Inflation Factor (VIF) dengan nilai lebih kecil dari 10. Hasil perhitungan ditunjukkan di Tabel 4.

Dari hasil perhitungan menunjukkan bahwa semua variabel bebas memiliki nilai VIF lebih kecil dari 10. Disimpulkan bahwa tidak ada multikolinieritas antar variabel bebas dalam model regresi pada penelitian ini.

Tabel 3: Hasil Uji Normalitas Distribusi

\begin{tabular}{lcc}
\hline \multicolumn{1}{c}{ Variabel } & K-S Z & 2 tailed p \\
\hline Sumber daya keuangan $\left(\mathrm{X}_{11}\right)$, Sumber daya fisik $\left(\mathrm{X}_{12}\right)$, Sumber daya & 0.934 & 0.348 \\
manusia $\left(\mathrm{X}_{13}\right)$, Sumber daya teknologi $\left(\mathrm{X}_{14}\right)$, Inovasi produk $\left(\mathrm{X}_{21}\right)$, dan & & \\
Sumber internal $\left(\mathrm{X}_{22}\right)$ untuk mencapai Keunggulan daya saing produk & & \\
$(\mathrm{Y})$ & & \\
\hline
\end{tabular}


Uji non-heteroskedastisitas (homoskedastisitas)

Pengujian menggunakan Uji Glejser, dengan $\mathrm{t}_{\text {hitung }}<\mathrm{t}_{\text {tabel }}$ dengan probabilitas di atas $5 \%$ sebesar 1.980 . Perhitungan diringkas di Tabel 5.

Hasil perhitungan menunjukkan bahwa semua variabel tidak dijumpai gejala hiteroskedastisitas atau terjadi homoskedastisitas.

\section{Uji non-autokorelasi}

Pendekatan Durbin-Watson (DW

test) digunakan untuk pengujian auto- korelasi, dengan DW lebih besar dari batas atas (du). Hasil perhitungan diringkas pada Tabel 6.

Hasil perhitungan DW yang menunjukkan nilai 1.677, atau lebih besar daripada batas atas (du) 1.65 , atau du $<$ DW $<4$-dl $(1.65<1.677<2.35)$. Dengan hasil tersebut dapat disimpulkan tidak terdapat autokorelasi positif dari model regresi pada penelitian ini.

Tabel 4: Uji Multikolinearitas Nilai Variance Inflation Factor (VIF)

\begin{tabular}{lcl}
\hline \multicolumn{1}{c}{ Varibel } & NILAI & KETERANGAN \\
\hline VIF & \\
Sumber daya keuangan $\left(\mathrm{X}_{11}\right)$ & 1.157 & Tidak ada indikasi kolinearitas antar variabel penjelas \\
Sumber daya fisik $\left(\mathrm{X}_{12}\right)$ & 1.222 & Tidak ada indikasi kolinearitas antar variabel penjelas \\
Sumber daya manusia $\left(\mathrm{X}_{13}\right)$ & 1.096 & Tidak ada indikasi kolinearitas antar variabel penjelas \\
Inovasi produk $\left(\mathrm{X}_{21}\right)$ & 1.155 & Tidak ada indikasi kolinearitas antar variabel penjelas \\
Sumber internal $\left(\mathrm{X}_{22}\right)$ & 1.560 & Tidak ada indikasi kolinearitas antar variabel penjelas \\
\hline
\end{tabular}

Tabel 5: Pengujian Asumsi Heteroskedastisitas Variabel BebasTerhadap Absolut Nilai

\begin{tabular}{lccl}
\multicolumn{4}{c}{ Residual $(\mathrm{Y})$ Dengan Menggunakan Uji Glejser } \\
\hline \multicolumn{1}{c}{ Variabel Bebas } & $\mathrm{T}_{\text {hitung }}$ & Sig & \multicolumn{1}{c}{ Interprestasi } \\
\hline Sumber daya keuangan $\left(\mathrm{X}_{11}\right)$ & 0.756 & 0.451 & Homoskedastisitas \\
Sumber daya fisik $\left(\mathrm{X}_{12}\right)$ & -1.436 & 0.074 & Homoskedastisitas \\
Sumber daya manusia $\left(\mathrm{X}_{13}\right)$ & -0.488 & 0.626 & Homoskedastisitas \\
Sumber daya teknologi $\left(\mathrm{X}_{14}\right)$ & -0.397 & 0.692 & Homoskedastisitas \\
Inovasi produk $\left(\mathrm{X}_{21}\right)$ & 0.478 & 0.633 & Homoskedastisitas \\
Sumber internal $\left(\mathrm{X}_{22}\right)$ & 1.163 & 0.248 & Homoskedastisitas \\
\hline
\end{tabular}

Tabel 6: Pengujian Asumsi Autokorelasi Variabel BebasTerhadap Keunggulan Daya Saing

\begin{tabular}{lrrrrrrr} 
& & \multicolumn{5}{c}{$\operatorname{Produk}(Y)$} \\
\hline No & & $\mathrm{dl}$ & $\mathrm{Du}$ & $4-\mathrm{du}$ & 4-dl & DW & Interprestasi \\
\hline & & & & & & & \\
1 & Nilai & 1.44 & 1.65 & 2.35 & 2.56 & 1.677 & Tidak ada autokorelasi \\
\hline
\end{tabular}




\section{Pembahasan}

Hasil perhitungan regresi berganda dengan signifikasi pada 0,05 diperoleh nilai $\mathrm{R}$ sebesar 0.660, menunjukkan bahwa pelaksanaan variabel strategi resource-based atas variabel sumber daya keuangan, sumber daya fisik, sumber daya manusia, sumber daya teknologi, dan strategi inovasi atas inovasi produk dan sumber internal dengan pendekatan biaya daur hidup produk mempunyai kemampuan cukup kuat sebesar $66 \%$ dalam upaya mencapai keunggulan daya saing produk, sedangkan nilai $\mathrm{R}^{2}$ sebesar 0.435, menunjukkan bahwa kemampuan variabel sumber daya keuangan, sumber daya fisik, sumber daya manusia, sumber daya teknologi, inovasi produk dan sumber internal dengan pendekatan biaya daur hidup produk dapat mencapai keunggulan daya saing produk secara berkesinambungan sebesar 43,5\%, sedangkan selebihnya sebesar $56,5 \%$ dijelaskan variabel lain yang tidak termasuk dalam persamaan model penelitian ini.

Hasil hipotesis atas dimensi-dimensi strategi resource-based dan inovasi dengan pendekatan biaya daur hidup produk mampu mencapai keunggulan daya saing produk secara berkesinambungan dapat diterima. Kalau dilihat dari besarnya kontribusi, tiga diantaranya (sumber daya fisik, inovasi produk, dan sumber internal) yaitu signifikan pada level 0,05. Sedangkan untuk sumber daya keuangan, sumber daya manusia dan sumber daya teknologi tidak mampu mendukung pencapaian keunggulan daya saing produk. Walaupun hasil perhitungan statistik tidak mempunyai kemampuan, namun dimensi ini tetap diharapkan, karena sumber-sumber yang ada pada dimensi strategi resource-based dan inovasi ini sangat dibutuhkan dalam usaha mencapai keunggulan daya saing produk. Berikut ini pembahasan tentang bagaimana masing-masing variabel strategi resourcebased dan inovasi dengan pendekatan biaya daur hidup produk bagi 108 UKM manufaktur di Jawa Timur untuk mencapai keunggulan daya saing produk.

Sumber daya keuangan, tidak memberikan hasil yang diharapkan untuk mencapai keunggulan daya saing produk, memberikan pemahaman bahwa pengelolaan sumber daya keuangan UKM manufaktur pada umumnya belum tertata dengan baik, karena segala aktivitas kegiatan keuangan atas penentuan perhitungan biaya selama proses pembuatan produk ditangani sendiri oleh pengelola (atau keluarga). Bukan karena pengelola UKM manufaktur tidak mau membagi tugas dalam pengelolaan keuangan, hal ini disebabkan masalah keuangan yang mengetahui hanya pengelola, sehingga sulit melakukan kontrol penggunaan keuangan yang benar-benar digunakan selama proses pembuatan produk, karena terkadang pengeluaran keluarga masuk di dalam perhitungan.

Sumber daya fisik, memberikan upaya UKM manufaktur untuk berusaha agar produk yang dihasilkan mampu dilakukan perincian biaya secara tepat, sehingga produk yang dihasilkan dapat mencapai kesesuaian antara manfaat dan harga yang diberikan, artinya harga produk yang diberikan tidak terlalu tinggi dan rendah.

Sumber daya manusia, menunjukkan ketidakmampuan mendukung pencapaian keunggulan daya saing produk UKM manufaktur, artinya tanggung jawab karyawan pada keberhasilan atas keakuratan dan efisiensi biaya produk selama proses produksi rendah, karena pengelola UKM manufaktur belum memprioritaskan upaya pengembangan tanggung jawab karyawan, sehingga karyawan hanya dikhususkan pada satu bidang kerja yang tidak mempengaruhi penentuan dan perhitungan biaya proses produksi produk dan tanggung jawab yang sedikit, adanya perasaan bahwa produk akan gagal apabila karyawan diberikan tanggung jawab pengelolaan biaya pembuatan produk, 
dan semakin karyawan mengerti keseluruhan proses penentuan biaya pembuatan produk akan dapat menjadi pesaing dikemudian hari apabila keluar, serta orientasi, kemampuan dan kewenangan dari pengelola usaha masih dominan dalam keputusan proses pembuatan dan kualitas produk.

Sumber daya teknologi, menunjukkan ketidakmampuan pencapaian keunggulan daya saing produk. Hal ini memperlihatkan bahwa UKM manufaktur tidak terlalu memperhatikan perkembangan teknologi pembuatan produk dalam pencapaian keakuratan dan efisiensi biaya, namun lebih mendasarkan pada kemampuan teknologi yang ada, karena lebih mampu menjalankan dan menghasilkan produk selama ini.

Inovasi produk, menunjukkan dengan didasarkan kreatifitas pengaruh besarnya tingkat generalisasi ide dan keberhasilan implementasi inovasi, kecukupan sumber daya dan dukungan manajemen dalam proses pembuatan produk untuk mencapai efisiensi dan keakuratan biaya produk dan keuntungan hasil akhir yang diinginkan, dihasilkan produk yang kreatif dengan didasarkan kemampuan internal perhitungan biaya selama proses pembuatan produk, dan produk yang dihasilkan mencerminkan pada kekuatan dan kelemahan sumber daya UKM manufaktur itu sendiri.

Sumber internal, bahwa dengan menciptakan kreativitas untuk mengembangkan dan mempertahankan keberhasilan usaha dari dalam atas kekuatan dan kelemahan sumber daya usaha yang dimiliki, untuk mencapai keakuratan hasil produk selama proses pembuatan dan hasil akhir atas tingkat keuntungan dan pengurangan resiko kerugian, akan didapatkan kemampuan UKM manufaktur memproduksi produk dengan tingkat keakuratan perhitungan biaya selama produk diproduksi.

Penghambat penerapan kedua strategi pada UKM manufaktur ini, yaitu kurangnya waktu pemahaman dan pengimplementasian konsep kedua strategi yang hanya mempunyai waktu selama 5 (lima) bulan yaitu bulan Juli sampai Nopember 2009, sehingga hasil nyata belum dapat sepenuhnya diamati. Akibatnya kurang memperhatikan keterkaitan antar dimensidimensi kedua strategi yang seharusnya saling memperkuat.

Faktor lain, yaitu kurangnya kesadaran dalam diri pribadi pelaku usaha UKM manufaktur akan pentingnya ilmu strategi yang dapat mendukung kesuksesaan hasil usaha apabila tanpa ada bukti atau contoh dari UKM lainnya yang menerapkan, rasa cepat puas diri atas hasil yang telah dicapai tanpa memperkirakan bahwa produk yang dihasilkan akan mengalami penurunan nantinya, ketidakteraturan melakukan perencanaan tertulis sumber daya yang digunakan selama proses pembuatan produk, apakah hasil produk berhasil, kurang berhasil atau gagal, dan penanaman jiwa pembaharuan atas produk yang dihasilkan memerlukan waktu dan kesadaran secara bertahap, serta kemampuan teknologi rendah.

\section{PENUTUP}

Berdasarkan hasil analisis regresi berganda diketahui bahwa strategi resourcebased (yaitu sumber daya keuangan, sumber daya fisik, sumber daya manusia dan sumber daya teknologi) dan strategi inovasi (yaitu inovasi produk dan sumber internal) dengan pendekatan biaya daur hidup produk secara simultan mampu untuk mencapai keunggulan daya saing produk bagi UKM manufaktur di Jawa Timur. Namun secara parsial hanya ada tiga variabel yang mampu mendukung pencapaian keunggulan daya saing produk yaitu sumber daya keuangan, inovasi produk, dan sumber internal. Walaupun menurut hasil perhitungan statistik hanya tiga variabel, namun ketiga variabel lainnya tetap diperhatikan oleh UKM manufaktur, karena hal paling mendasar atas pelaksanaan 
strategi, yaitu keterkaitan antar keseluruhan dimensi harus saling mendukung dan memperkuat.

Pengembangan strategi resourcebased dan inovasi ini diharapkan dapat memberikan kontribusi bagi UKM manufaktur Jawa Timur, untuk menumbuhkan kesadaran pentingnya konsep strategi bersaing yang bersumber dari internal UKM melalui strategi resource-based dan inovasi dengan pendekatan biaya produk selama daur hidupnya, yang akan dapat menciptakan efektivitas dan keakuratan biaya selama proses pembuatan produk, dan penetapan harga yang sesuai dengan perhitungan biaya yang terjadi dengan pendapatan yang diperkirakan, sehingga keunggulan daya saing produk usahanya dapat dicapai dan dipertahankan secara berkesinambungan atas dasar kekuatan dan kelemahan yang dimiliki oleh UKM manufaktur itu sendiri.

Penelitian ini memiliki keterbatasan antara lain: terbatasnya waktu pemahaman dan pelaksanaan selama 5 (lima) bulan yaitu bulan Juli sampai Nopember 2009, akibatnya kurangnya memperhatikan keterkaitan antar dimensi-dimensi kedua strategi yang seharusnya saling memperkuat, kemudian penentuan sampel penelitian yang terfokus pada UKM manufaktur di Jawa Timur mitrabinaan LPM Universitas Brawijaya (UB) Malang dengan PT. Danareksa, sehingga hasil penelitian belum dapat disimpulkan sebagai hasil keseluruhan untuk kondisi UKM manufaktur di Jawa Timur. Hasil penelitian yang terfokus pada pelaksanaan variabel strategi resource-based dan inovasi, mengakibatkan hasil penelitian lebih kepada pemahaman masing-masing strategi, belum kepada bagaimana kedua strategi saling memberikan pengaruh. Kelemahan lainnya bahwa penelitian ini lebih memfokuskan kapabilitas internal tanpa melihat kapabilitas eksternal, sehingga keakuratan hasil pelaksanaan strategi lebih kepada kemampuan internal.
Terlepas dari berbagai keterbatasan yang dimiliki, hasil penelitian ini merupakan langkah awal yang telah mencoba mengimplementasikan keberhasilan penerapan konsep strategi resource-based dan inovasi pada kapabilitas internal UKM manufaktur. Dengan demikian untuk para peneliti berikutnya jika ingin meneliti strategi tersebut disarankan; pelaksanaan bimbingan lebih intensif dan waktu penelitian lebih lama lagi, sehingga keberhasilan dan hasil nyata yang didapatkan akan lebih dapat diketahui. Selanjutnya di dalam penentuan sampel yang dijadikan penelitian UKM manufaktur lebih luas cakupan wilayahnya, untuk dapat lebih mencerminkan keseluruhan kondisi UKM manufaktur tersebut, dan kemungkinan untuk menerapkan pada jenis usaha lain seperti; koperasi, UKM jasa maupun perusahaan besar.

Memungkinkan penggunaan dimensi keseluruhan dari strategi resource-based (atas sumber daya keuangan, fisik, manusia, teknologi, dan reputasi organisasi) dan strategi inovasi (atas orientasi aktivitas desain, proses produksi, inovasi produk, sumber eksternal, sumber internal, dan tingkat investasi), sekaligus dimungkinkan pula memasukkan strategi inovasi pada keseluruhan dimensi strategi resouce-based yang menjadi fokus penelitian, dan mengikutsertakan partisipasi konsumen dan pemasok sebagai responden agar lebih memberikan keakuratan hasil pelaksanaan strategi tersebut.

\section{DAFTAR PUSTAKA}

Baswir, R. (1998). Tantangan Dan Peluang Pengembangan Usaha Kecil Dalam Era Perdagangan Bebas. Jurnal Ekonomi dan Bisnis Indonesia, 13 (1), 72-79.

Black, J.A. and Boal, K.B. (1994). Strategic Resources: Traits. Configurations and Paths To Sustainable 
Competitive Advantage. Strategic Management Journal, 15. Special Issue, Summer, 131-148.

Butler, J.E. (1988). Theories of Technological Innovation As Useful Tools For Corporate Strategy. Strategic Management Journal, 9, Jan/Feb, 15-29.

Departemen Koperasi dan Pembinaan Pengusaha Kecil. (1995). UndangUndang Nomer 9 Tahun 1995 Tentang Usaha Kecil.

Dollinger, M.J. and Golden, P.A. (1992). Interorganizational and Collective Strategies In Small Firms: Environmental Effects and Performance. Journal of Management, 18 (4), 695-715.

Drucker, P.F. (2002). The Discipline of Innovation. Harvard Business Review, August, 95- 102.

Emblemsvaq, J. (2001). Activity-Based Life-Cycle Costing. Managerial Auditing Journal, 16 (1), 17-27.

Gaskill, L.R., Van Auken, H.E. and Manning, R.A. (1993). A Factor Analytic Study of The Perceived Causes of Small Business Failure. Journal of Small Business Management, 31 (4), 18-31.

Grant, R.M. (1991). The Resource-Based Theory of Competitive Advantage: Implications for Strategy Formulation. California Management Review, 33 (3), 114-135.

Grant, R.M. (1999). Contemporary Strategy Analysis Concept. Techniques. Applications. Two Edition. 1995. Blackwell Publisher. Inc. Thomas Secokusumo (penterjemah). Analisis Strategi Kontemporer
Konsep. Teknik. Aplikasi. Jakarta: Penerbit Erlangga.

Hariadi, B. (2002). Akuntansi Manajemen Suatu Sudut Pandang. Edisi Pertama. Yogyakarta: BPFEYogyakarta.

Hariadi, B. (2003). Strategi Manajemen: Strategi Memenangkan Perang Bisnis. Edisi Pertama. Malang: Penerbit Bayumedia.

Hebert, F.J., and Brandley, J.H. (1993). Expert Systems Development In Small Business: A Managerial Perspective. Journal of Small Business Management, 31 (3), 23-34.

Human, S.E. and Provan, K.G. (1997). An Emergent Theory Of Structure And Outcomes In Small-Firm Strategic Manufacturing Networks. Academy of Management Journal, 40 (2), 368-403.

Khan, A.M. and Manopichetwattana, V. (1989). Innovative and NonInnovative Small Firms: Types and Characteristic. Management Science, 35 (5), 597-606.

Kuncoro, M. (1996). Struktur Dan Kinerja Industri Indonesia Setelah 50 Tahun Merdeka: Adakah Peluang Kecil?. Jurnal Ekonomi, 2 (7), 2-14.

LaBahn, D.W., Ali, A. and Krapfel, R. (1996). New Product Development Cycle Time: The Influence of Project and Process Factors in Small Manufacturing Companies. Journal of Business Research, 36 (2), 179-188.

Liang, Z., Peien, F.. and Shuangxia, P. (2001). Cost Engineering for Product Design. AACE International Transactions, EST (12), 1- 6. 
Lovas, B. and Ghoshal, S. (2000). Strategy As Guided Evolution. Strategic Management Journal, 21 (September), 875-896.

Mahoney, J.T. (1995). The Management of Resources and the Resource of Management. Journal of Business Research, 33 (2), 91-101.

Mahoney, J.T. and Pandian, J.R. (1992). The Resource-Based View Within The Conversation Of Strategic Management. Strategic Management Journal, 13 (June), 363-380.

McGrath, R.G., Tsai, M.H., Venkataraman, S. and MacMillan, I.C. (1996). Innovation. Competitive Advantage and Rent: A Model and Test. Management Science, 42 (3), 389-403.

Miller, D. and Friesen, P. (1984). Organizations: A Quantum View. Prentice-Hall. Inc.

Mosakowski, E. (1993). A Resources-Based Perspective on the Dynamic Strategy-Performance Relationship: An Empirical Examination of the Focus ang Differentiation Strategies in Entrepreneurial Firms. Journal of Management, 19 (4), 819-839.

Mosakowski, E. (1998). Managerial Prescriptions Under The Resources-Based View of Strategy: The Example of Motivational Techniques. Strategic Management Journal, 19 (12), 1169-1182.

Mulyadi, (2001). Akuntansi Manajemen: Konsep. Manfaat dan Rekayasa. Edisi 3. Jakarta: Penerbit Salemba Empat.

Nugent, J. B. and Yhee, S.J. (2002). Small and Medium Enterprises In Korea: Achievements. Constraints and
Policy Issues. Small Business Economics, 18, 85-119.

Onkvisit and Shaw. (1986). Competition and Product Management: Can the Product Life Cycle Help?. Business Horizons, July-August, 51-62.

Porter, M.E. (1993). Competitive Advantage: Creating and Sustaining Superior Performance. 1985. Macintosh SE. Agus Dharma dkk (penterjemah). Keunggulan Bersaing: Menciptakan dan Mempertahankan Kinerja Unggul. Jakarta: Penerbit Erlangga.

Porter, M.E. (1996). What Is Strategy?. Harvard Business Review, 74 (6), 61-78.

Rindova, V.P. and Fombrun, C.J. (1999). Constructing Competitive Advantage: The Role of Firm-Constituent Interactions. Strategic Management Journal, 20 (8), 691-710.

Saadah, N. (2002). Usaha Kecil dan Menengah. Yogyakarta: Pusat Studi Asia Pasifik UGM.

Schroeder, R.G., Bates, K.A. and Junttila, M.A. (2002). A Resource-Based View of Manufacturing Strategy and The Relationship To Manufacturing Performance. Strategic Management Journal, 23, 105-117.

Setyawan, A.A. (2004). Pengaruh Customer Orientation terhadap Kinerja Usaha Kecil-Menengah: Kasus Sentra Industri Mebel Serenan. Klaten. Jawa Tengah. Usahawan, 33 (4), 12-19.

Suryana (2003). Kewirausahaan: Pedoman Praktis. Kiat dan Proses Menuju Sukses. Edisi Revisi. Jakaarta: Penerbit Salemba Empat. 
Tatikonda, M.V. and Rosenthal, S.R. (2000). Successful Execution of Product Development Projects: Balancing Firmness and Flexibility in The Innovation Process. Journal of Operations Management, 18, 401-425.

Triyuwono, I. (1999). Gagasan Terbesar Bisnis Kecil/Menengah Kunci Utama Indonesia Menghadapi Krisis: Kewirausahaan Perusahaan
(Corporate Entrepreneurship): Kajian Akuntansi Bisnis. Seminar Regional Sehari. 21 Oktober. Malang: Lembaga Manajemen Fakultas Ekonomi Universitas Brawijaya.

Vinnell, R. and Hamilton, R.T. (1999). A Historical Perspective on Small Firm Development. Entrepreneurship Theory and Practice. Summer. 5-18. 